\title{
Speech acts produced by Brazilian teachers of English in online professional self-presentations - a case study
}

\author{
Elisa Mattos de Sá \\ Universidade Nova de Lisboa
}

\begin{abstract}
This paper presents a discourse analysis of speech acts identified in professional online self-presentations of Brazilian teachers of English. Its objective is to show that examinations based exclusively on the traditional analytical assumptions of the Speech Act Theory, as proposed by Searle $(1969,1976,1979)$ and Searle \& Vanderveken (1985), fail to grasp the many roles context plays in the linguistic materialization of this phenomenon. Thus, a more comprehensive analysis is suggested, employing the notions of micro and macro speech acts as theorized by van Dijk (1977a, 1977b, 1977c); this kind of analysis proves to be a more suitable framework for understanding the communicative purposes and the complexity of online professional self-presentations.
\end{abstract}

Keywords: Speech Acts. Professional Self-presentation. Context.

\begin{abstract}
Resumo
O presente artigo desenvolve uma análise discursiva de atos de fala identificados em apresentações profissionais on-line de professores brasileiros de inglês, objetivando mostrar que exames baseados exclusivamente nos pressupostos analíticos tradicionais da Teoria dos Atos de Fala, vistos em Searle $(1969,1976,1979)$ e Searle e Vanderveken (1985), não conseguem abordar os papéis que o contexto desempenha na materialização linguística desse fenômeno. Assim, sugere-se uma análise mais abrangente, empregando as noções de atos de fala micro e macro, como teorizadas por van Dijk (1977a, 1977b, 1977c), que revela ser mais adequado para a compreensão dos objetivos comunicativos e da complexidade das apresentações profissionais on-line.
\end{abstract}

Palavras-chave: Atos de Fala.Apresentações Profissionais.Contexto.

\section{INTRODUCTION}

If we think about written professional self-presentations, it is safe to assume that such texts present various speech acts with high informative content in assertive form - even in more informal situations. The term professional presentations is hereby employed differently from that of Goffman (1956). In this paper, "self-presentation" strictly refers to the genre of presenting oneself, much as autobiographies do, that is, intended at introducing someone by means of 
essential information display. In this sense, professional presentations are likely to contain set assertive phrases such as "I have $\mathrm{X}$ years of experience in $\mathrm{Z}$ area" and "Following a master's degree in Y, I did a PhD in W", or "I am an expert in X, Y and Z". Strictly speaking, professional self-presentations aim at doing just that: they are a socially accepted tool for professionals to present themselves in a concise way, by adding a description of their qualifications, skills, and experience.

However, it would be naïve to believe that professional self-presentations do only that, as even the more traditional ones are designed to produce positive professional images. In this sense, professional self-presentations can be understood as serving two purposes: a) introducing the professional by means of a succinct professional description and b) promoting the professional, by highlighting positive, favorable attributes and accomplishments. Therefore, it is equally safe to presume that the speech acts thereby employed may not be restricted to assertive sentences, since the communicative purpose intended goes beyond assertion and description.

Seeing that "genres are abstract, socially recognized ways of using language and represent how writers typically respond to recurring situations" (HYLAND, 2016, p. 120), and because they reflect underlying social (and ideological) structures of a given time and place (BAKHTIN, 2016), it is possible to understand professional self-presentations today as mirroring a wide range of social phenomena, materialized in discourse. This means that professional selfpresentations might well surpass the functions listed above, as we increasingly witness a process of self-promotion fueled by the affordances of online communication (ATTRIL, 2015; SCHAU \&GILLY, 2003).

This paper is concerned with understanding speech acts employed in online professional self-presentations of Brazilian teachers of English. With a focus on the macro and micro level of discourse, the case study presented here was guided by the following research questions: a) What individual speech acts can be identified in these texts?; b) How are the sequences of speech acts organized in the presentations?; and c) What is the self-presentations' overall speech act framework and communicative purpose?

The first section of this paper is an overview of the website from which the data were extracted, followed by a brief account of the Speech Acts Theory and a discourse perspective of the phenomenon. The corpus and the methodology are then discussed, accompanied by an analysis of a selected professional self-presentation and final remarks on the topic. 


\section{PROFESSIONAL SELF-PRESENTATIONS ONLINE}

The advent of the Internet has undoubtedly revolutionized the way people use, teach, and learn languages. From the so-called "Netspeak" (CRYSTAL, 2006) to YouTube channels in which language functions and sounds are carefully explained, many are the changes and the possibilities the Internet has brought to both teachers and students of English as a Foreign Language (EFL). The website italki $^{1}$ is one such option. Defined as a language learning social network (FU \& CAO, 2014) and a social media-based language learning website (STANLEY, 2015), italki caters online classes in more than 90 languages, with professional teachers from all over the world. As of the date of production of this paper, 1,771 teachers had been registered at the website, 1,070 of which teach English. Out of this number, 28 are Brazilian.

Considering the role of English in an ever more complex, internationalized world, it is not surprising to see such a high number of people interested in teaching English, since this has become the language of business, science, travel, and the Internet (CRYSTAL, 2006). It seems natural, therefore, to have non-native teachers of English- and not just native ones- offering their teaching services both in their home countries and online. In this sense, the long-held native speaker myth seems to have dissipated.

At italki all teachers need to produce a presentation of themselves to accompany a profile photo, in addition to describing language skills, teaching specialties, rates. Teachers must also add a professional curriculum vitae (work experience, education, and certificates), ratings and number of students and lessons given (for teachers whose classes have already been hired and rated), as well as a presentation video, among other features ${ }^{2}$. Professional self-presentations are expected to include information about the teachers, with utterances such as "I have a degree in [relevant information]", "I have worked as a teacher for [number] years", which are formulaic of this genre.

Information accuracy is verified by italki before teachers produce their self-presentations, as they must upload scanned copies of their teaching certificates prior to setting up the profiles. Such copies are then manually checked by the italki team. Teachers are also encouraged to

\footnotetext{
${ }^{1}$ www.italki.com.

${ }^{2}$ Since the focus of this paper is not on a thorough description of this genre, other profile features will not be presented. I redirect the reader to the italki website for further information and visualization on such elements.
} 
maintain a professional image: the website provides general guidelines for the video presentation and for profile photo. However, there are no specific instructions for self-presentations. Differently from LinkedIn, which "explicitly discourages any forms of self-expression or emotional attachments" (VAN DIJK, 2013, p. 208), italki does not constrain its users, which may result in more freedom to use language, thus creating fertile ground for unconventional or perhaps unexpected (for the genre) constructions in the making of the professional selfpresentations.

This is indeed the case: the corpus of this research shows that many presentations contain informal expressions or greetings, such as "Hi there" (presentation 1), "Welcome, and thanks for checking out my profile!” (presentation 5), and "Hello everybody!” (presentation20), which seem more typical of social networks such as Facebook than professional websites. As an affordance ${ }^{3}$ of computer-mediated communication (CMC) and online genres, the self-presentations also contain paralinguistic elements such as emoticons and more informal language constructions the free use of contracted forms is an example, as observed in figure 1 below.

Figure 1: italki professional self-presentation

\footnotetext{
${ }^{3}$ I refer the reader to Gibson (1979) for the original concept of affordance, a notion that is now widely used in research on CMC, as discussed in Baron (2008).
} 


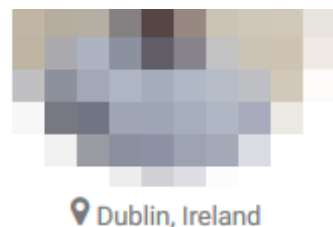

14:40 UTC+00:00
Professional Teacher From Brazil

Teaches Portuguese, English

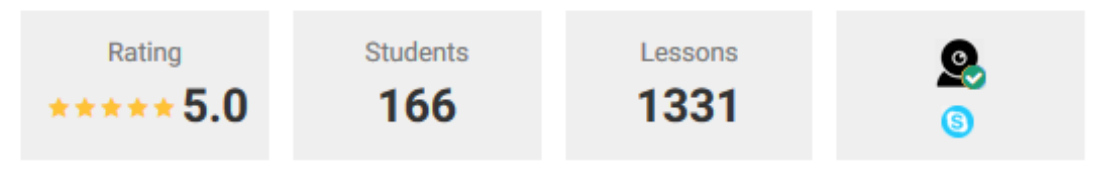

Language Skills: Portuguese IIIII , English IIIII , Spanish IIII , Chinese (Mandarin) IIIII, GermanIIIII

Teaching Specialities: Beginners Teenagers Business Test Preparation IELTS TOEFL

Personal tags: Material Preparation Neutral Accent PTE Attentive Supportive Punctual

Teacher since: Feb 22, 2016

Hello! My name is Andre. I was born in Brazil, but I've also lived in the United States. Right now, I'm living and studying in Ireland, at Dublin City University - DCU. In addition, I hold a professional teaching certification (TESOL), an IELTS certificate of 8.0, a post degree in IT and many years of experience in this field. Because l've studied English for many years, I know what the struggles of learning a new language are and I also have plenty of textbooks, handouts, and other resources to boost your learning process. I can provide you with all the material to support our classes. It also contributes to make this experience much more interactive and fruitful. Basically, it will be much more than just chatting on Skype. I understand that learning a new language can be challenging, so I promise you to be patient and helpful. I also know every language learner has different interests, so if you have a special topic you are interested in learning, please do not hesitate to contact me and our classes will be tailored to your needs.

\section{SPEECH ACTS THEORY}

Speech acts are utterances that aim to achieve some sort of effect or action. As "basic or minimal units of linguistic communication" (SEARLE, 1969, p.16), they convey a state of mind or involvement in interactions (cf. AUSTIN, 1962; SEARLE, 1969). According to Austin (1962), when a speech act is produced, three types of acts are simultaneously performed: a) the locutionary act, which is the utterance itself; b) the illocutionary act, which presupposes a force dependent on the utterance's semantic content; and c) the perlocutionary act, which is aimed at creating certain effects on the addressee(s). Moreover, Austin proposed the study of felicity conditions involved in the performance of speech acts - or the appropriate elements and circumstances for a speech act to be successfully recognized in interaction ${ }^{4}$.

Searle $(1969,1976,1979)$ elaborated on Austin's theory by focusing on the intentionality of speech acts, based on the semantic content of sentences, through which an illocutionary force and a perlocutionary effect are derived, that is, we understand what a speaker intends to achieve

\footnotetext{
${ }^{4}$ Due to restrictions of space, I direct the reader to the original writings of Austin (1962) and to Bosco (2009), who presents a full account of the Speech Act Theory, including its philosophical influences and theorizations.
} 
when producing an utterance by identifying the force and the effect of that sentence. Searle (1976, 1979) also developed a taxonomy for speech acts: a) assertives: commit the speaker(s) to a state of affairs; b) commissives: commit the speaker(s) to future actions; c) directives: are used to get the other interaction participant to carry out an action; d) declaratives: create an immediate change of affairs; and e) expressives: convey a psychological state. As is widely accepted in the literature, within Searle's categorization, speech acts "could be extended to several hundred" (GRIFFITHS, 2006).

Additionally, speech acts can also be regarded as direct and indirect(cf. SEARLE, 1975). Based on Searle's theorizations, Yule (2010) explains that interrogative structures usually function as questions, while imperative and declarative constructions may work as commands/requests and statements, respectively. An interrogative such as "Do you speak English?" constitutes a question that requires the respondent to provide (exactly) the information inquired. This is therefore a direct speech act. An indirect speech act is an act whose syntactic structure does not match its underlying function. For instance, "Can you speak up?" takes the form of a question, but may be meant as "Please speak up", which is a request.

Research on speech acts is largely based on the studies of Austin (1962) and Searle (1969, 1976, 1979), who attempted to describe and understand the complexity behind what we say and do with words. Critiques of these authors usually pertain to the fact that their theorizations have been applied to fabricated and isolated sentences and not to examples retrieved from real-life discourse situations (STREEK, 1980). In fact, Austin (1962)had already stressed the importance of including elements from the whole speech situation in the examination of speech acts.

Traditional pragmatic investigation, however, has heavily relied on Searle (1979, 1976, 1969) and Searle \& Vanderveken (1985) for categorization and analysis, focusing on the utterances that compose the speech act, as well as on its intentionality. Thus, following a formal model does not comprehensively account for macro elements in interactions. As we shall see, the online professional self-presentations selected for this research are better served with a more inclusive analytical system, which will be discussed as follows.

\section{MICRO AND MACRO SPEECH ACTS: A DISCOURSE FRAMEWORK}


As noted by van Dijk (1977b), speech acts are an essential part of social interaction, and context plays a key role in this process, as it controls discourse production and comprehension ${ }^{5}$ (VAN DIJK, 2005). Thus, utterances are regarded as being produced in interaction and organized within different layers of communication, with a number of contextual features that have to be considered when thinking about a pragmatic or discursive approach.

A promise, for instance, it not merely deemed as such simply because it contains a sentence with a verb that semantically conveys this state: several factors contribute to its making - the speakers' social roles, the genre supporting the communication to the promise content and the preceding speech acts that create the (textual-discursive) conditions for the successful production of the promise. As van Dijk (1977a, p.11) puts it: "the meaningfulness of composite sentences and pairs of sentences depends on the macro-structure. ...the semantics of sentences and that of sequences and discourses cannot be dissociated from each other".

Van Dijk (1977b) also states that the interpretation of a speech act should include three kinds of information: a) the general semantic information of the linguistic constructions, which the speakers activate from memory; b) the information from immediately preceding events/acts; and c) the global information about the entire interaction. In other words, analyzing speech acts requires a localized, thorough examination of the semantic structures that compose the speech acts as well as an inspection of the sequences of other acts that support the discourse.

From this perspective, speech acts are seen as part of a framework that is organized linearly and hierarchically: a communicative situation contains a number of individual or micro speech acts that can be grouped in sequences. These sequences form macro speech acts meant to be interpreted as a unit (VAN DIJK, 1977c) and help to set the conditions for the final communicative purpose. The macro speech acts' structure - and even the existence of an intermediate layer of sequences, as we will see in the sample analysis - depends on the complexity of the discourse situation.

A simple illustration of how speech acts work from a micro and macro level is seen in marriage proposals, which are conventionally realized by the question Will you marry me? The conditions for the realization of this speech act involve a sequence of other individual speech acts that are also part of the proposal. These acts could be grouped in a mini-narrative unit, for example, when the speaker narrates how they met their partner, thus setting the ground for the

\footnotetext{
${ }^{5}$ Van Dijk (2006) provides an in-depth discussion of context as an interface between social structure and discourse.
} 
proposal question. The proposal may be seen as the macro speech act - a larger unit - as it encompasses all other preceding speech acts, including the proposal question, which, in fact, may or may not be linguistically materialized as a question, as it is the case with less conventional versions.

An approach based on the assumptions discussed in this section seems to offer a more comprehensive analytical apparatus for research on speech acts. While it is helpful to identify speech acts as assertions or promises, as simple or complex - and naturally, the semantic content of utterances is essential -, it is only by associating all speech acts with the context within which they have been performed that we begin to unravel their overall organization and effect.

\section{UNDERSTANDING THE CORPUS}

The corpus collected for this research initially contained 28 professional selfpresentations produced by Brazilian teachers of English at italki, totaling 5,086 words ${ }^{6}$, distributed in English and other languages. These texts were first saved in a single Word file and thoroughly examined for content through a pragmatic analysis of the information conveyed in each sentence or passage, guided by the following questions:

1) What type of information does this sentence/passage convey? (e.g. information about the teacher, about his/her skills and qualifications etc.); and

2) What was the teacher trying to achieve with this information?

The presentations also included content that was not produced by the teachers, such as testimonials from students and poems. The tables below indicate the additional languages (table 1) and the additional content (table 2) identified in the corpus, and their sum (table 3), including number of presentations and number of words for each language and each type of additional content.

Table 1: additional languages

\begin{tabular}{|c|c|c|}
\hline Additional Languages & No. of presentations & No. of words \\
\hline Portuguese & 9 & 1,014 \\
\hline Spanish & 2 & 82 \\
\hline Italian & 1 & 78 \\
\hline
\end{tabular}

\footnotetext{
${ }^{6}$ Information such as cancellation policy, sometimes shown at the end of the original presentations, have not been included in the corpus, as they pertain to class logistics and are not considered mechanisms of self-presentation.
} 


\begin{tabular}{|c|c|c|}
\hline Arabic & 1 & 21 \\
\hline Polish & 1 & 68 \\
\hline Total & $\mathbf{1 4}$ & $\mathbf{1 , 2 6 3}$ \\
\hline
\end{tabular}

able 2: additional content

\begin{tabular}{|c|c|c|}
\hline Additional Content & No. of presentations & No. of words \\
\hline Testimonials & 2 & 81 \\
\hline Poems & 1 & 89 \\
\hline Total & $\mathbf{3}$ & $\mathbf{1 8 0}$ \\
\hline
\end{tabular}

Table 3: Total sum of information deleted from the initial corpus

\begin{tabular}{|c|c|c|}
\hline \multicolumn{3}{|c|}{ Sum of Additional Languages and Content } \\
\hline Total Additional Languages & 14 presentations & 1,263 words \\
\hline Total Additional Content & 3 presentations & 180 words \\
\hline Total & $\mathbf{1 7}$ presentations & $\mathbf{1 , 4 3 3}$ words \\
\hline
\end{tabular}

Since the aim of this research was to analyze speech acts produced in English by Brazilian teachers, all information presented in languages other than English was removed from the initial corpus. Hence, two presentations fully elaborated in Portuguese were also discarded. Considering that two testimonials and the poem found in one presentation were not originally written by the teachers, such content was also removed. Therefore, the final corpus encompasses 26 presentations totaling 3,653 words, the shortest presentation containing 16 words and the longest comprising 313 words.

Firstly, each presentation was saved in a separate Word file, where individual speech acts were identified and color-coded, with the corresponding verb or phrase that linguistically indicates each speech act type marked in matching colors. Speech act identification at the microlevel of discourse relied on semantic structure within sentence boundaries. Once the individual speech acts had been identified, break lines were added to the text for better visualization.

The individual speech acts identified were then examined within their immediate context to determine whether they formed sequences of acts that could be grouped together, outstripping the individual level. The grouped sequences were hierarchically marked to indicate their position in discourse and different hierarchical levels were established in the texts, with some act sequences categorized as intermediate speech acts. As previously mentioned, intermediate-level speech acts help to create the conditions for macro speech acts. 
Each presentation in the corpus was then annotated twice: one annotation for each different sequence and a second annotation for their representation in the texts under investigation. Once the overall framework of the speech acts was determined, the communicative purpose of each online professional self-presentation was also established: an analysis was carried out at the micro level (the structure of individual speech acts) and at the macro level (overall communicative structure) of discourse.

\section{SPEECH ACT SEQUENCES IN CONTEXT}

This section presents examples of speech acts identified in the corpus and discusses a sample analysis of a professional self-presentation specifically selected for this paper. The analysis encompasses micro and macro speech acts, taking into account both the more immediate and the larger context, and shows how the data was treated, that is, it visually displays (in figure 1) how the micro and macro speech acts were organized and the communicative purpose of the presentations was established.

At the micro level of discourse, many presentations contained assertive speech acts: "I have two international certifications" (seen in presentation 4), "I usually design my classes according to each student's needs, which makes the whole learning process easier" (presentation 5), "I can explain grammatical points, practice vocabulary and most importantly help you develop your oral proficiency" (presentation 7), and "I know what it means to learn a language, and the different techniques necessary to become fluent" (presentation 17).

These are assertive speech acts with high informative semantic content - and a localized analysis of the speech acts identified in the texts show that much of the content of the presentations does rely on assertions aimed at providing the readers with information about the teachers. However, once we analyze the sequence of assertive speech acts from immediate to more general context, we notice that most sequences are actually targeted at persuading italki users. This makes sense, as the professional self-presentations at the learning website should function not only as a way for teachers to introduce themselves but also as (indirect) advertisements of their teaching services.

The self-presentation below is one such example, as it displays the hierarchical organization of the speech acts mapped in the sample text selected for this paper. The example is 
color-coded: assertions in red, a promise act in green, a directive act in purple, a concession in yellow, and a greeting in blue. This example was visually structured taking into account the sequences of speech acts, that is, considering both the micro and the macro levels of discourse.

Figure 2: a micro and macro speech acts framework

G Hello!

A My name is Andre

A I was born in Brazil

A but I've also lived in the United States

A Right now, I'm living and studying in Ireland (...)

A In addition, I hold a professional teaching certification (...)

A [I hold] an IELTS certificate of 8.0

A [I hold] a post degree in IT

$A$ and [I hold] many years of experience in this field

A Because l've studied English for many years

A I know what the struggles of learning a new language are

$A$ and $I$ also have plenty of textbooks, handouts, (....)

A I can provide you with all the material (...)

A It also contributes to make this experience (...)

A Basically, it will be much more than just chatting on Skype

A I understand that learning a new language can be challenging

$P$ so I promise you to be patient and helpful

A I also know every language learner has different interests

$C$ so if you have a special topic you are interested in learning

$D$ please do not hesitate to contact me

$A$ and our classes will be tailored to your needs.

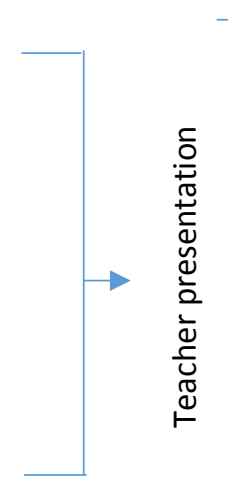

Speech act categorization is found on the left hand side of each individual act: $G$ is for "greeting", A for "assertion", P for "promise", C for "concession" and D stands for "directive". In matching colors are the corresponding verb or phrase that assigns the type of speech act at this level. This is the micro-level of the speech act framework for this text, which is followed by an 
intermediate level of speech act sequences, grouped according to the communicative purpose to which they refer.

Thus, we have a group of sequences that compose the "Teacher Presentation", a smaller and more specific set related to the "Lesson Presentation", located within the "Teacher Promise". Both the "Teacher Presentation" and the "Teacher Promise" are on the same level of discourse as the "Teacher Concession and Commitment". This level forms the macro speech act of "Teacher Offer", which contains all the other semantic and pragmatic information of the previous speech act sequences. This teacher's self-presentation starts as such, but in reality, it functions as an offer that contains a self-presentation.

We see from an analysis such as this that "the interpretation of a discourse as a specific speech act (or series of speech acts) is embedded within an interpretation of the whole interaction process" (VAN DIJK \& KINTSCH, 1983, p.7). A simple assertion such as "I understand that learning a new language can be challenging" cannot be analyzed in isolation, as it encompasses all other previous acts in that sequence.

Moreover, the "Teacher Presentation" works as a preparatory intermediate speech act, with the assertive individual acts that antecede the promise developing the conditions for its linguistic materialization: "I've studied English for many years" and "I know what the struggles of learning a new language are" support "I understand that learning a new language can be challenging", ultimately leading to "so I promise you to be patient and helpful". The promise the teacher makes does not depend solely on an individual speech act, but on the association of this sequence of acts in this particular situation.

Certainly, pragmatic markers such as "because" and "so" also play a role in supporting the overall structure of the promise, as they semantically indicate reason and effect and help to sustain the (discourse) conditions for the promise. This self-presentation would probably not have the same effect had these markers not been included. Furthermore, as a professional who wishes to attract future students, this teacher understands how important it is to put himself in the learners' shoes, a meaning conveyed in this sequence of speech acts: "I've studied English for many years", "I know what the struggles of learning a new language are" and "I understand that learning a new language can be challenging" are assertions that place the teacher in the position of the student, drawing on personal experience and projecting empathy - perhaps as an attempt to create a bond with potential clients. 
It is interesting to notice that the effect of most speech acts in this text truly depends on other speech acts. It is the case with "I also have plenty of textbooks, handouts, and other resources to boost your learning process". Yes, the teacher may have a lot of material to offer future students, but what matters here is that it is implicit that such materials will be part of the classes and that the teacher knows how to use them. This inference is supported by the subsequent speech acts, when the teacher explains how the material can be used and how the classes are going to be conducted.

Van Dijk (1977a, p. 244-45) notes that "what is important information not only depends on the semantic structure of the text but also on the pragmatic functions of the discourse." This means that all elements in a given interaction deserve attention and must be investigated. In this sample, for instance, there are discourse strategies that convey a clear engagement goal from the teacher to potential learners: the pronouns "you", "your", and "our". Engaging with the readers in such a direct way certainly helps to build persuasion and to set the pragmatic conditions for the teaching offer.

\section{CONCLUSION}

Considering that the ample context plays a key role in speech acts analysis from a discourse perspective, it is also possible to say that the final communicative purpose of the selfpresentation analyzed in this paper is guided by the affordances of the genre and of the website. As previously stated, italki requires that teachers create profiles and produce self-presentations in the process of seeking new students via the learning network. The website works as a platform and the content of the presentations relies on the teachers' discursive abilities in presenting themselves online.

Naturally, not all self-presentations in the corpus display the same discourse organization such as the one selected for this paper: some are shorter, without greetings or promises; others are longer and interestingly not as assertive. What they have in common, however, is a high incidence of speech acts of self-discourse that do not constitute only self-presentations - rather, the sequences compose macro speech acts aimed at persuading the readers to seek the teachers' classes. This confirms the need for more comprehensive analyses of speech acts that go beyond 
the individual, micro level of realization and encompass the macro-structure of discourse, as opposed to focusing exclusively on speaker intentionally, utterance force, or categorization.

\section{REFERENCES}

ATTRIL, A. The Manipulation of Online Self-Presentation: Create, Edit, Re-edit and Present. New York: Palgrave Macmillan, 2015.

AUSTIN, J. How to do things with words. London: Oxford University Press, 1962.

BAKHTIN, M. Os gêneros do discurso.Paulo Bezerra (Organização, Tradução, Posfácio e Notas).Notas da edição russa: Seguei Botcharov. São Paulo: Editora 34, 2016.

BARON, N. Always On: Language in an Online and Mobile World. New York: Oxford University Press, 2008.

BOSCO, F. M. Cognitive Pragmatics. In: MEY, J. L. Concise Encyclopedia of Pragmatics. 2nd edition. Oxford: Elsevier, 2009.

CRYSTAL, D. Language and the Internet.2nd edition. New York: Cambridge University Press, 2006

FU, Q. \& CAO, X. Preliminary Study to the Inquiry Learning Social Network Supported by the Internet of Things. In: CHIU, D. K. W. et al. (Eds.) New Horizons in Web Based Learning: ICWL 2011 International Workshops, KMEL, ELSM, and SPeL, Hong Kong: Springer, 2014.

GIBSON, J. J. The Ecological Approach to Visual Perception. Boston: Houghton Mifflin, 1979.

GOFFMAN, E. The Presentation of Self in Everyday Life. New York: Anchor Books, 1959.

HYLAND, K. Methods and methodologies in second language writing research. System, v. 59, pp. 116-125, 2016.

SEARLE, J. R. Expression and Meaning: Studies in the Theory of Speech Act. Cambridge: Cambridge University Press, 1979.

. A classification of illocutionary acts. California: University of California, 1976.

. Indirect Speech Acts. In: COLE, P.; MORGAN, J. (Eds.) Syntax and Semantics, v. 1, n. 3. New York: Academic Press, 1975.

. Speech Acts. An Essay in the Philosophy of Language. Cambridge: Cambridge University Press, 1969. 
SEARLE, J. R., VANDERVEKEN, D. Foundations of Illocutionary Logic. Cambridge: Cambridge University Press, 1985.

SCHAU, H. J.; GILLY, M. C. We Are What We Post? Self-Presentation in Personal Web Space. Journal of Consumer Research, v. 30, n. 3, pp. 385-404, 2003.

STANLEY, P. Talking to Strangers. In: NUNAN, D.; RICHARDS, J. C. (Eds.). Language Learning Beyond the Classroom. New York: Routledge, 2015.

STREEK, J. Speech acts in interaction: A critique of Searle. Discourse Processes, v. 3, n. 2, pp. 133-154. West Germany: Free University of Berlin, 1980.

VAN DIJK, J. You have one identity: performing the self on Facebook and LinkedIn. Media, Culture \& Society. v. 35, n. 2, pp. 199-215. London: Sage Publishing, 2013.

VAN DIJK, T. A. Discourse, context and cognition. Discourse Studies. v. 8, n.1, pp. 159-177. London: SAGE Publications, 2006.

.Contextual knowledge management in discourse production. A CDA perspective. In: WODAK, R.; CHILTON, P. (Eds.)A New Agenda in (Critical) Discourse Analysis. Amsterdam: Benjamins, 2005.

Text and Context: Explorations in the semantics and pragmatics of discourse. London: Longman, 1997a.

. Context and Cognition: Knowledge frames and speech act comprehension. Journal of Pragmatics, v. 1, pp. 211-232, 1977 .

. Pragmatic macrostructures in discourse and cognition. In: DE MEY, M.et al. (Eds.) CC 77 International Workshop on the Cognitive Viewpoint, Communication \& Cognition, pp. 99-113. University of Ghent, 1977c.

VAN DIJK, T. A.; KINTSCH, W. Strategies of discourse comprehension. New York, London: Academic Press, 1983.

YULE, G. The Study of Language. New York: Cambridge University Press, 2010.

.Pragmatics. New York: Oxford University Press, 1996.

\section{A AUTORA}

Elisa Mattos de Sá é mestranda em English Language Teaching na Universidade Nova de Lisboa, colaboradora do CETAPS (Center of English, Translation and Anglo-Portuguese Studies), na mesma universidade, onde investiga o uso de tecnologias digitais no ensinoaprendizagem de inglês. Especialista em Ensino de Inglês pela Universidade Federal de Minas 
Gerais (2009), tem licenciatura dupla em Letras: Português e Inglês pela Pontifícia Universidade Católica de Minas Gerais (2005) e é professora de inglês há 17 anos.

E-mail: mattos.elisa@gmail.com 